Georgetown University Law Center

Scholarship @ GEORGETOWN LAW

2000

\title{
Willard Hurst and the Administrative State: From Williams to Wisconsin
}

Daniel R. Ernst

Georgetown University Law Center, ernst@law.georgetown.edu

This paper can be downloaded free of charge from:

https://scholarship.law.georgetown.edu/facpub/592

18 Law \& Hist. Rev. 1-36 (2000)

This open-access article is brought to you by the Georgetown Law Library. Posted with permission of the author. Follow this and additional works at: https://scholarship.law.georgetown.edu/facpub

Part of the Administrative Law Commons, and the Legal History Commons 


\title{
Willard Hurst and the Administrative State: From Williams to Wisconsin
}

\author{
DANIEL R. ERNST
}

Perhaps because Willard Hurst did not publish his first book, The Growth of American Law, until 1950, more than a decade after he entered law teaching, his readers have often found it hard to imagine him as other than a fully formed scholar. The pluralist politics of his major writings, their functionalist sociology, and their attentiveness to consensus in history have made Hurst seem so much a product of the 1950 s that one can easily overlook the ways in which developments in law and politics in the preceding decades shaped his perspective on the American past. ${ }^{1}$

No development more engaged Hurst than "the overshadowing rise of the administrative process" since the Civil War. Without neglecting the continuing role of the judiciary in American governance, Hurst wanted to create a legal curriculum and jurisprudence to supplant the court-centered paradigms of his day. The curricular innovation came first, in the form of the

1. James Willard Hurst, The Growth of American Law: The Law Makers (Boston: Little, Brown, 1950).

Daniel R. Ernst is a professor of law at Georgetown University Law Center. He thanks Robert W. Gordon, Laura Kalman, Alfred S. Konefsky, Stanley Kutler, Charles W. McCurdy, Clyde Spillenger, Christopher L. Tomlins, Mark V. Tushnet, Victoria Saker Woeste, and two anonymous reviewers for their comments on drafts of this article; participants of seminars at the University of Wisconsin-Madison Law School and the American Bar Foundation for their remarks on this article or related work; Clark Byse, Frances W. Hurst, Stanley I. Kutler, Charles F. Luce, and Willard Wirtz for their recollections of Willard Hurst; the archivists Monica Blank, Sylvia Kennick Brown, Cathy Jacob, Harold L. Miller, Lori Olson, Jeffrey Suchanek, and David Warrington for their assistance in making available documents in their collections; Mr. Hugo L. Black, Jr., for permission to examine the papers of Justice Black; and Thomas Andrews, Mary Calkins, Patrick J. McClain, and Jessica Schneider for their research assistance.

Law and History Review Spring 2000, Vol. 18, No. 1

(C) 2000 by the Board of Trustees of the University of Illinois 
"Law in Society" materials that Hurst, with the collaboration of his dean, Lloyd K. Garrison, developed at the University of Wisconsin Law School in the 1930s. The statement of a jurisprudence to replace judicial norms of due process, formal styles of legal reasoning, and a notion of the Rule of Law premised on judicial review under written constitutions was harder work. Not until Hurst published his great legal history of Wisconsin's lumber industry, Law and Economic Growth, in 1964 did he feel that he had finally practiced what Roscoe Pound had only preached by articulating a "sociological jurisprudence" based on the ideal of law as a functional means to "a socially acceptable end."2

This article follows Hurst from his undergraduate days at Williams College through the start of his teaching career at Wisconsin in the fall of 1937. During these years Hurst acquired an abiding interest in the rise of the administrative state as well as some of the insights he would use to account for it in his mature work. For the most part, the article proceeds chronologically through four episodes in Hurst's training: (1) his year-long study of Charles and Mary Beard's Rise of American Civilization undertaken as an undergraduate at Williams College; (2) his three years as a student at the Harvard Law School; (3) his research fellowship with Felix Frankfurter during the 1935-36 academic year; and (4) his service as legal secretary to Louis D. Brandeis during the October 1936 Term of the U.S. Supreme Court. The first and third episodes inclined Hurst to see history less as an aid to the judicial interpretation of precedents, statutes, and constitutions than as a way to divine where the state should strike the "balance of power" in regulating the American economy and society. The second and fourth episodes show that Hurst embraced the Legal Realists' skepticism toward judge-made law, but also went beyond them to address that "large field of present human activity ... governed not alone by court decisions and statutes, but by administrative regulations and decisions." More enthusiastically than his mentors Frankfurter and Brandeis, Hurst accepted the growth of unreviewable discretion by administrators, and he was quicker to accord "the regulations, rulings and decisions of administrative agencies" the same status as judge-made law. ${ }^{3}$

2. Willard Hurst, "Who Is the 'Great' Appellate Judge?" Indiana Law Journal 24 (1949): 396; James Willard Hurst, Law and Economic Growth: The Legal History of the Lumber Industry in Wisconsin, 1836-1915 (Cambridge, Mass.: Harvard University Press, 1964); Willard Hurst, "J. Willard Hurst: An Interview Conducted by Laura L. Smail" (Madison: University Archives Oral History Project, University of Wisconsin-Madison, 1981), 25 (hereafter Hurst, Smail Interview); James Willard Hurst, "Legal Elements in United States History," Perspectives in American History 5 (1971): 3.

3. "Administrative Law," Curriculum Committee Report No. 8, 1947, Box 5, Series 11/1/ 2, University of Wisconsin Archives, Memorial Library, Madison (hereafter Subject Files, WLS-UWA). 
Each of the four episodes contributed something to Hurst's mature understanding of the Rule of Law in the new American state, but their lessons did not add up to a complete answer. His experiences of the late 1930s and 1940s taught him new lessons and gave him cause to discard or rework what he had already learned. A complete account of the origins of Hurst's mature work would have to address his activities as a law professor before Pearl Harbor, his service in Washington's wartime bureaucracies, and his period of study under a Demobilization Grant of the Social Science Research Council. ${ }^{4}$ Even so, a study of Hurst's education and apprenticeships is enough to suggest how much his social history of American law owed to the political history of his young adulthood.

\section{Conflict and Consensus in American History}

Particularly because much of the functionalist social science of the 1950s had a teleological cast and treated such phenomena as the rise of the administrative state as inevitable or necessary, one should remember that Willard Hurst, born on October 6, 1910, came of age during the Great Depression, when the American economy self-evidently was not functioning and when the ultimate success of new experiments in administration was very much in doubt. That society functioned as well as it did was always cause for amazement for Hurst, little short of a "miracle," as James Gould Cozzens, one of his favorite novelists, put it, the performance of a seemingly impossible feat of social organization "every day, come hell, come high water." 5 The critic Elizabeth Janeway once wrote that the heroes of Cozzens's novels were men who understand "the way things worked, the functioning of the world." They live with these functions, "interpret them for others and in some part keep the machinery running. Able, responsible men, more burdened by duty than eager for power, learning in maturity that one never really knows enough, stoically bearing the weight of the world - these are the men Cozzens sets up as admirable." Hurst

4. Hurst's year at the Board of Economic Warfare is the subject of my forthcoming article, "The Ideal and the Actual in the State: Willard Hurst at the Board of Economic Warfare," in Total War and the Law: New Perspectives on World War II, ed. Daniel R. Ernst and Victor Jew (East Lansing: Michigan State University Press, 2000).

5. James Gould Cozzens, The Just and the Unjust (New York: Harcourt, Brace, 1942), 434. Hurst called The Just and the Unjust and Cozzens's Guard of Honor (1948) "the best fiction anyone has done about the law in this country." Hurst to Frankfurter, 12 January 1949, reel 42, Felix Frankfurter Papers, Library of Congress (hereafter FF-LC). Frances Hurst and Stanley Kutler have assured me that Cozzens and John P. Marquand were among Hurst's favorite authors. Frances Hurst, interviewed by author, Madison, Wis., 12 May 1998; Stanley Kutler, conversation with author, Madison, Wis., 13 May 1998. 
agreed that Cozzens's heroes were admirable, and, like Cozzens himself, he assigned to lawyers "a key administrative role in making this complex, division-of-labor-society operate from day to day."'

As far as we know, Hurst first started thinking seriously about the relation of law to "historical and economic currents" while a student at Williams College, which he attended from 1928 to 1932. Born and raised in Rockford, Illinois, where his father had been the superintendent of a piano factory and the co-owner of most of the town's movie theaters, Hurst settled on Williams out of what he later termed "a rather romantic attachment to the idea of going to college in New England." He recalled, "It in some ways was a rather rough atmosphere to come into for a young fellow from a Midwest high school, because Williams was at that point still much dominated by a student-body drawn from Eastern prep schools who set the whole social tone and pretty much ran the politics of the place." He never joined a fraternity, but concentrated his energy on his studies, at which he excelled; on the student newspaper, where he was editor in chief; and on the International Affairs Club, which he served as secretary and president. An economics major who published a prize-winning essay on the Low Countries' response to the English Gold Crisis of 1931, Hurst took almost as many courses in history, and he became captivated by the perspective the past provided on the relationship between the economy and governmental processes. ${ }^{7}$

The principal focus for Hurst's thinking on this subject was a senior honors tutorial, directed by the historian Theodore Clarke Smith during the 1931-32 academic year, in which he and Smith argued about Charles and Mary Beard's recently published Rise of American Civilization. Hurst read the book enthusiastically and thought it represented "the whole new light of history." Smith thought it "phony and pretentious." Judging from the broadside Smith fired at Charles Beard several years later in the American Historical Review, he would have told Hurst that Beard's "economic theory of history" rendered him incapable of pursuing Ranke's "noble dream" of historical impartiality. Beard believed that "the only valid history was that which traced the forward movement of society toward a collectivist democracy," Smith insisted. By making history the servant of

6. Elizabeth Janeway, review of The Novels of James Gould Cozzens, by Frederick Bracher, New York Times Book Review, 9 August 1959, 1; Willard Hurst, "Lawyers in American Society, 1750-1966," Marquette Law Review 50 (1967): 600.

7. Hurst, Smail Interview, 1-2, 18; Williams College, Gulielmensian (1932), 69; "Belgium, Holland, and Switzerland and the English Gold Crisis of 1931," 23 April 1932, Archives and Special Collections, Williams College Library; Willard Hurst, "Holland, Switzerland, and Belgium and the English Gold Crisis of 1931," Journal of Political Eccnomy 40 (1932): 63860 . 


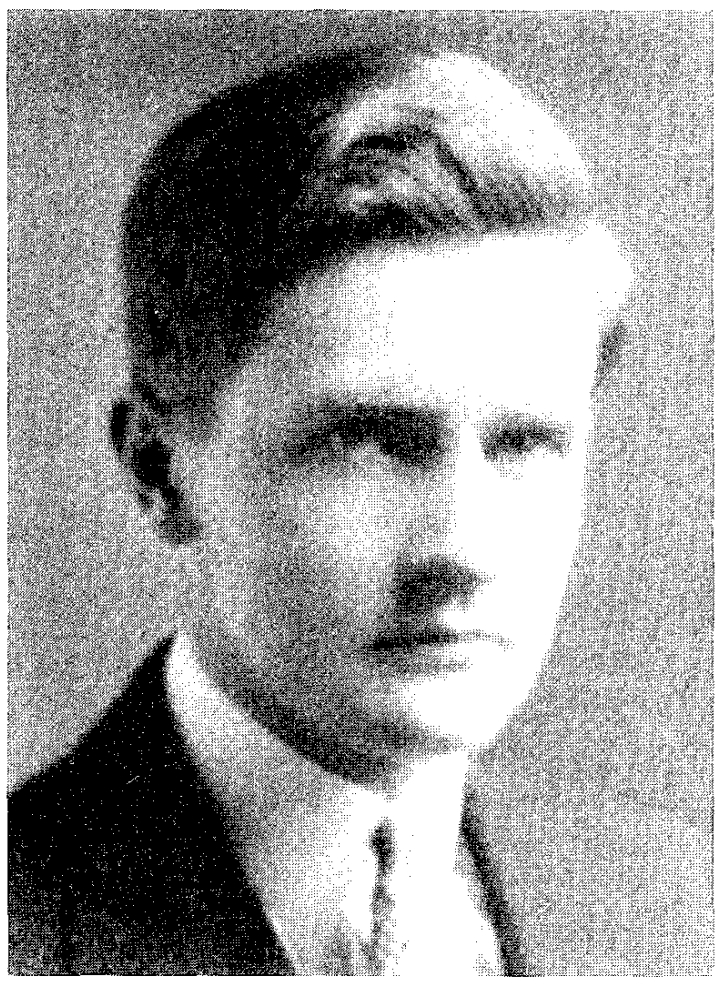

Fig. 1. James Willard Hurst, Williams College Gulielmensian, 1933. Courtesy of Williams College Archives and Special Collections.

politics, Beard was traveling down a path blazed by Soviet, Fascist, and Nazi historians. ${ }^{8}$

Hurst was never fully persuaded by Smith. In the 1950s he listed Charles Beard's Economic Interpretation of the Constitution of the United States as one of the books "any lawyer whose interest in his profession reaches beyond technical craftsmanship" should read. ${ }^{9}$ Moreover, Hurst often invoked the Beards' view of the Civil War as a Second American Revolution to justify his slighting of colonial America. Thus, in 1952 he urged upon Frankfurter "Charles Beard's thesis" that "the United States had a

8. Hartog, "Snakes in Ireland," Law and History Review 12 (1994): 371; Theodore Clarke Smith, "The Writing of American History in America, from 1884 to 1934," American Historical Review 40 (1935): 447-49. Hurst retained his heavily annotated copy of Rise of American Civilization throughout his life, and it has become something of an heirloom in his family. Frances Hurst, interview.

9. "Social Science on a Lawyer's Bookshelf," n.d., in Frankfurter to Hurst, 10 May 1956, reel 42, FF-LC. 
second birth in the 1870 's," which made the late nineteenth-century lawmakers as much a founding generation as the Framers. Hurst might trace "middle class values" back to the English Civil War, but he had little use for colonial American legal history, and he dismissed eighteenth-century Anglo-American law as too riven with corruption and incompetence to be worth studying. His interest picked up once he detected the social forces he associated with modernization, such as "the rise of large scale industry and finance, the flow of immigration, urbanization, the fixing of the modern character of major political parties, [and] the rise of new style lobbies." 10 The Beards' project of creating a usable past for a modernizing society, then, inspired Hurst to take a presentist approach to the past. He could make his history the servant of his jurisprudence and not feel the qualms that a scholar with other historical heroes might have felt. ${ }^{11}$

Well before the 1950s, however, Hurst grew dissatisfied with a Beardian approach to the past as little more than the clash of conflicting interests. Consequently, he looked to consensual theories of social function to supplement the Progressive historian's tales of social conflict. At times he spoke of Charles Beard almost as a youthful enthusiasm.

In his second year of law teaching, for example, Hurst told Frankfurter of a seminar on the history of the Supreme Court he was planning with William Hesseltine, perhaps the most passionate Progressive in Wisconsin's Beardian history department. Hesseltine was "a good man by all accounts," Hurst explained, "also somewhat of a left-winger. His approach of course has been of the Beard variety: economic interpretation largely, with concentration on the major and more spectacular cases." Hurst hoped to "tackle something less obvious than the usual big cases and derive some light therefrom either as to American growth generally, or at least to" the development of the Court. Changes in diversity jurisdiction in the antebellum period, for example, might offer "a slant on the business of making federalism work" or on the growth of national commerce. ${ }^{12}$

In 1939 Hurst reviewed several works that took issue with the Beards' claim in Rise of American Civilization that the drafters of the Fourteenth Amendment intended its guarantee of equal protection and due process to

10. Hurst to Frankfurter, 27 July 1952, reel 42, FF-LC; J. Willard Hurst, "Modern American Legal History" (Madison: Wisconsin Public Radio, 1978), cassette 1, side 1.

11. See Stanley N. Katz, "The Problem of a Colonial Legal History," in Colonial British America: Essays in the New History of the Early Modern Era, ed. Jack P. Greene and J. R. Pole (Baltimore: Johns Hopkins University Press, 1984), 465-66.

12. Peter Novick, That Noble Dream: The "Objectivity Question" and the American Historical Profession (New York: Cambridge University Press, 1988), 345; Hurst to Frankfurter, 27 February 1938, Box 192, Felix Frankfurter Papers, Harvard Law School Library (hereafter FF-HLS). 
"persons" to be the vehicle for smuggling rights for corporations into the Constitution. A more defensible position, Hurst implied with an approving quote of Howard Jay Graham, was that the doctrine that corporations were persons was "so vital and natural a part of the self-expansion of judicial power within the framework of due process, that its postwar development was assured, whatever may have been the original objectives of the framers."'13

By the early 1940s, Hurst was quite ready to move beyond interest as a historical cause, but when the war came he had only begun to envision how social process and function might serve as alternatives. Pendleton Herring's pluralist account of the American polity, The Politics of Democracy, which Hurst reviewed in 1941, came as a revelation. Herring argued that interest-group politics was a remarkable achievement, the peaceful adjustment of social conflict. "This emphasis may seem nothing novel to men of an older teaching," Hurst wrote, perhaps with Smith in mind, "but it may cause some revision of values among readers of my college generation, taught to regard the political historian as one naively skirting the realities dealt with by the students of economic and social trends." ${ }^{14}$ Hurst would not read systematically in the works of anthropology, sociology, and social psychology and fashion an alternative to Beard until his Demobilization Grant. At that point Richard Hofstadter, another borrower from sociology and psychology, would surpass Beard in his pantheon of historians. ${ }^{15}$

\section{Outgrowing the Harvard Law School: Legal Realism and the Administrative Process}

Hurst seriously considered pursuing a graduate degree in economics, but he ultimately decided that he wanted to learn about the law from the standpoint of legal insiders, the lawyers themselves. "The logical place to go, especially for anybody who'd been four years in Williamstown," Hurst recalled, "seemed to be the Harvard Law School," and so he went. When he entered the school, Hurst had not yet decided how he would use his legal education. While he did want to "become a good lawyer," he did not nec-

13. Willard Hurst, review of Truth and Fiction about the Fourteenth Amendment, by Louis B. Boudin, Harvard Law Review 52 (1939): 851, 858.

14. Willard Hurst, review of The Politics of Democracy, by Pendleton Herring, Harvard Law Review 54 (1941): 715, 717.

15. Hurst recommended Hofstadter's American Political Tradition and Social Darwinism in America to Frankfurter and placed both books and The Age of Reform on his list of recommended readings for the Wisconsin bar in 1956. Hurst to Frankfurter, 12 January 1949, reel 42, FF-LC; "Social Science on a Lawyer's Bookshelf," n.d., ibid. 
essarily expect to become a practitioner, and he soon set his sights on a career as a legal academic. ${ }^{16}$

For this scholarly, thoughtful, and capable student, the case method of Harvard's first-year curriculum was a disappointment, an "unimaginative brand of good, solid tradesmen's education." 17 In part, he missed the close relationship he had had with his teachers at Williams. Harvard was "a very cold, impersonal place," he recalled. The faculty was "quite remote." Those who labored on the Restatement projects, he told Brandeis, sat "in Langdell Hall and gloat[ed] over citations of themselves with a miser's pleasure." 18 The alienation was only partially alleviated by Hurst's success on his examinations and his growing sense of accomplishment and ability. "You sort of figured that at the end of your first year at the Harvard Law School if you could survive and make it there you could probably survive and make it any place," he remembered. ${ }^{19}$

Hurst's dissatisfaction was compounded by Harvard's pedagogy. As practiced by such master Langdellians as Samuel Williston, who taught him contracts, the case method struck Hurst as willfully blind to the most exciting and novel aspects of law in the Depression era, as well as the economic and political dimension of judicial decision making that the Beards memorably explored in the Rise of American Civilization. The relentless study of cases and courts provided almost no opportunity to explore legislation and administration. (Hurst would have to wait until his year as Frankfurter's research assistant before he could attend a course on legislation.) Moreover, his instructors analyzed case law as a matter of legal logic, "an exercise in Euclid's geometry." That Williston, a sophisticated man of business, taught the law as if it were "a separate and distinct piece of reality" remained a mystery to him. ${ }^{20}$

\section{The Lessons of Legal Realism}

As an antidote to the case method, Hurst prescribed for himself a course of reading in the work of Karl Llewellyn and other Legal Realists. In

16. Hurst, Smail Interview, 2-3; Hartog, "Snakes in Ireland," 373.

17. Hurst to Lloyd K. Garrison, 3 June 1946, Box 5, Lloyd K. Garrison Papers, Harvard Law School Library.

18. Hurst, Smail Interview, 3-4; "No. 17, Mechanics Universal Joint Co. v. Culhane, Re. draft of opinion," n.d., 19, reel 26, series 2, Louis Dembitz Brandeis Papers, Harvard Law School Library (hereafter LDB-HLS). The particular Restater Hurst had in mind might have been Warren Seavey, as Culhane involved the law of agency and one of the notes Hurst edited for the Harvard Law Review referred extensively to Seavey's restatement of that field of law. "Liability of Directors and Other Agents for Procuring Breach of Corporate Contract," Harvard Law Review 48 (1934): 298-302.

19. Hurst, Smail Interview, 3.

20. Hartog, "Snakes in Ireland," 377, 372-73. 
Llewellyn's writings on the law of sales Hurst found the exciting story of the interplay between law and economic forces that was so exasperatingly absent in Williston's contracts course. Llewellyn conveyed the notion that "the law of sales had something to do with the way an American economy worked and developed." And that "something" was thought of in functional terms, as a contribution to the proper working of particular societies in distinct times and places. The functional approach to law would be for Hurst the most important contribution of Legal Realism. "A realistic history of law in the United States," he later wrote, "will be a social history of law, taking law as man-made, and as the product of both deliberation and drift, but not of any immanent superior order of reality."21

The social origins of law and the implication for the common law of contract, tort, and property were recurrent themes in Hurst's mature work. At the most fundamental level, Hurst attacked the notion of individuals as independent bearers of natural rights that constrained the public realm of policy-making, arguing instead that "men realize their humanity only in a social context." He paused to make this point during his legal history lectures with a blast at the Gilded Age's worship of "what was called 'the selfmade man." It was "certainly one of the most vain characterizations of human nature anybody ever succeeded in inventing," he snorted. "As if any individual could be "self-made" — as if any individual did not owe "the society into which he is born" an enormous debt for "an immense heritage" in the form of language and accumulated social knowledge "for which he hadn't paid a cent."'22

Such views informed Hurst's understanding of the "regulatory implications" of the consideration doctrine and other aspects of contracts law. "Insofar as the law undertakes to enforce private agreements," he explained to his students, "to that degree it is in effect delegating the power of the state to those people who want to enforce their contracts, and to that extent the state is sanctioning what these contracting parties want to bring about." And if private rights were in fact publicly created, judges could not pretend that they were simply deferring to a distinct realm of natural justice in deciding whether to enforce a contract. Had the U.S. Supreme Court decided to enforce a racially restrictive covenant in Barrows v. Jackson,

21. James Willard Hurst, "Legal Elements," 28. For Llewellyn's influence on Hurst, see Hartog, "Snakes in Ireland," 372-73, 381; Aviam Soifer, "In Retrospect: Willard Hurst, Consensus History, and The Growth of American Law," Reviews in American History 20 (1992): 141, n. 14. And on the functionalism of Llewellyn and other Legal Realists, see Laura Kalman, Legal Realism at Yale, 1927-1960 (Chapel Hill: University of North Carolina Press, 1986), 3-44; N. E. H. Hull, Roscoe Pound and Karl Llewellyn: Searching for an American Jurisprudence (Chicago: University of Chicago Press, 1997), 136-47.

22. Hurst, "Legal Elements," 84; Hurst, "Modern American Legal History," cassette 17, side 2. 
Hurst argued, it would of course have been acting on its own authority to see to it that the public power was used responsibly. It had also acted on the same mandate when it refused to enforce the covenant in that case. ${ }^{23}$

An opportunity to demonstrate his grasp of what Hurst considered the "basic" insight of Legal Realism came during his term as Brandeis's legal secretary in a case involving picketing by trade unionists. Senn v. Tile Layers Protective Union was a constitutional challenge to a Wisconsin statute that forbade courts from prohibiting peaceful picketing. It was brought by a nonunion contractor who employed one or two workers but also labored on his jobs himself. Senn argued that by forbidding courts from issuing injunctions against strikes on his jobs Wisconsin was failing in its duty to protect his "inalienable right" to "work in his own business with his own hands." The statute violated the Fourteenth Amendment's guarantee of due process, he insisted, and was void. ${ }^{24}$

Brandeis's draft opinion attempted to parry Senn's argument by distinguishing between an act of the state, for which a Fourteenth Amendment claim could be made, and an omission to act, for which the requisite "state action" was missing. In effect, Brandeis argued that the state of Wisconsin had not inflicted economic loss on the contractor; the trade unionists had. Much like the Legal Realist Walter Wheeler Cook, Hurst objected that Brandeis's resort to the act-omission distinction ducked the difficult issue of whether the state should recognize and confirm the defendant's power to inflict economic loss on the plaintiff. "True, the State does not by affirmative fiat take away plaintiff's right to work himself," Hurst told Brandeis, "but what of the practical effect of leaving the unions free to exert strong pressure to the same end?" Brandeis's opinion should acknowledge that the Court was "in the realm of choice," Hurst advised. The "State's decision to leave one property owner in 'freedom' may inescapably mean a decision to impose restrictions upon the 'freedom' of another." 25

Hurst's belief in the public origins of private rights had far-reaching implications. It suggested that the rights of interest groups and other collec-

23. Hurst, "Modern American Legal History," cassette 31, side 2; Barrows v. Jackson, 346 U.S. 249 (1953).

24. Hurst, "Modern American Legal History," cassette 31, side 2; Senn v. Tile Layers Protective Union, 301 U.S. 468 (1937).

25. "No. 658, Senn v. Tile Layers Protective Union (Wis. Sup. Ct. 1936), Re. draft of opinion," 19 April 1937, 20-21, reel 26, LDB-HLS. Hurst supported his argument with a citation to Miller v. Schoene, 276 U.S. 272, 279 (1928), in which Justice Harlan Fiske Stone explained the decision to uphold a statute authorizing the destruction of cedar trees for the benefit of apple growers with the remark that "it would have been none the less a choice" had the state decided not to enact the statute. For Cook on Brandeis's resort to the act-omission distinction in International News Service v. Associated Press, 248 U.S. 215, 260-61 (1918), see "The Associated Press Case," Yale Law Journal 28 (1919): 387-91. 
tive actors were also the products of a prior collective choice. As Hurst later wrote, incorporation statutes, public subsidies, the opening of national markets, and "the freedom which law gave for association" created an astounding array of interest groups to which politically organized Americans readily deferred throughout the nineteenth century, rather than claim "the planning of social policy" for themselves. Laissez-faire was not a natural condition; the real meaning of this "myth" was "our deep adherence to the institution of the market as the device to determine where economic decision-making should rest." The establishment of public utility commissions, the revitalization of antitrust law, and a host of other systerns of inspection, licensure, and regulation were not novel intrusions into the private realm, but a reassertion of the public's preexisting right to strike "the balance of power" among state-created entities by intervening at "key points in social organization." The fundamental question, Hurst would argue to Mark DeWolfe Howe in 1949, was "Who Runs the Show"? "Control of the economy" had been entrusted at various times to various groups, including "labor union heads and corporation bureaucrats and government bureaucrats." Those who run "the show without having taken an official oath of office and those who run at least part of the show on the basis that they have taken an oath of office" were equally accountable for their use of public power. ${ }^{26}$

The case method depicted law as an apolitical process of deduction from abstract principles arrived at through induction from decided cases. Hurst found an alternative to this in the Legal Realists. Yet their functional approach to law provided at best only a point of departure for understanding the command-and-control regulation, licensure and inspection, taxation, social insurance, social provision and other forms of administrative action that burgeoned in the twentieth century. The Legal Realists, Hurst later explained, made "only a limited" break with the Langdellian curriculum. For the most part, they were interested in "the courts, and in a more realistic understanding of what moves judges to decide the way they do." Hurst was convinced, as he later put it, that "statutes and administrative rules and precedents" provided "principled or predictable lines of public policy," and not simply "arbitrary exercises of will." But where, at the Harvard Law School, might he find help in understanding the actions of those who "ran the show" within the state but outside the courts? ${ }^{27}$

26. Hurst, Law and the Conditions of Freedom in the Nineteenth-Century United States (Madison: University of Wisconsin Press, 1956), 82, 84, 85, 89; James Willard Hurst, "Law and the Balance of Power in the Community," Record of the Association of the Bar of the City of New York 6 (1951): 155; Hurst to Mark DeWolfe Howe, 22 June 1949, Box 3, Mark DeWolfe Howe Papers, Harvard Law School Library.

27. Hurst, Smail Interview, 19; James Willard Hurst, "Old and New Dimensions of Research in United States Legal History," American Journal of Legal History 23 (1979): 3. Like 


\section{The Frankfurterian Beacon}

The most promising candidate was Felix Frankfurter, who had made the teaching of legislation and administrative law his specialty since joining the faculty in 1914. Hurst encountered Frankfurter in his course on the Interstate Commerce Act, worked with him closely while editing several student notes on administrative law during the 1934-35 academic year, and audited his graduate course on administrative law during his year as Frankfurter's research assistant. He read Frankfurter's influential statement on the place of law in the administrative state, The Public and Its Government (1930), no later than his third year of law school, when he edited a note citing the book. ${ }^{28}$

Frankfurter's acceptance of the rise of administration made him a beacon for Hurst. The growth of administrative government, Frankfurter insisted, was no perversion of the timeless constitutional principle of separation of powers but "the inevitable response of government to the needs of modern society." Frankfurter conceived of those needs as vast, material forces, such as "technology, large-scale industry, and progressive urbanization." 29 His casebooks provided an expansive view of administration, ranging from the Interstate Commerce Commission (ICC) to workers' compensation commissions to a host of state-level systems of "licenses, certificates, permits, orders, awards, and what not." So variegated a development could not have been the product of a particular political philosophy or act of "far-sighted planning," Frankfurter maintained. Rather, it resulted from the "pressure of circumstances." 30

Hurst, Neil Duxbury has stressed the limits of the Legal Realists' contribution to the New Deal state, in his Patterns of American Jurisprudence (New York: Oxford University Press, 1995), 149-58.

28. Hurst, Smail Interview, 10; Hartog, "Snakes in Ireland," 373; Hurst to Frankfurter, 2 June 1954, reel 42, FF-LC; Felix Frankfurter, The Public and Its Government (New Haven: Yale University Press, 1930); "The Chicago Telephone Case: A New Technique in Rate Review," Harvard Law Review 48 (1934): 83, n. 2. In 1981, Hurst explained that he had "some connection with" Frankfurter "growing out of my law review editor's work. ... [T] here was always consultation with relevant faculty members on whatever the subject matter made appropriate, and in the normal course of dealing . . I I got to know various faculty members in a way I never would have just as another student at the school." Hurst, Smail Interview, 8.

29. These quotations are from Felix Frankfurter, "The Task of Administrative Law," University of Pennsylvania Law Review 75 (1927): 617, and a subsequently published and slightly revised version of the same essay, Preface to the First Edition (1932), in Felix Frankfurter and J. Forrester Davison, Cases and Materials on Administrative Law (Chicago: Foundation Press, 1935), v.

30. Frankfurter and Davison, Administrative Law, 570-74; Frankfurter, Public and Its Government, 29, 133. 
According to Frankfurter, the complexity of the problems of modernity would frustrate any technocratic solution offered by experts wielding an "irrefragable fund of knowledge." The American people were not up to the job, either. They were too "hurried," too "hostile to reflection," and more interested in scandal than "a knowledge of the good in government." Politicians could only see government as a source of patronage; they were responsible for the appointment of "mediocre lawyers" to administrative bodies, who fell far short of Frankfurter's ideal bureaucrats, the members of the British civil service. ${ }^{31}$

The challenge for American educators, Frankfurter wrote, was to produce administrators with the proper "intellectual procedure and ... temper of mind," a procedure and temper that bore a remarkable resemblance to the qualities that Roscoe Pound believed the common law tradition imparted to American lawyers. The best administrators, such as the ICC's Joseph B. Eastman, were "fortified" by their technicians but not overwhelmed by them. They independently performed the "quiet, detached, laborious task of disentangling facts from fiction, of extracting reliable information from interested parties, of agreeing upon what is proof and what surmise." They were as independent of "the actual or supposed wishes or needs even of the President as is the Supreme Court of the United States." (On the other hand, they were responsive to the "constant play of criticism by an informed and spirited bar.") If the administrators did all this, then they would enjoy "an esteem in the public such as the public now entertains for the judiciary," if only because they were scarcely distinguishable from judges, as Frankfurter idealized them. ${ }^{32}$

Hurst followed Frankfurter in seeing administrative action, such as Wisconsin's system of worker's compensation, in functional terms, as a response to "the force of facts." He agreed that the American public was not up to the job of governance, especially when the return of prosperity after World War II distracted them with consumer goods. Legislative oversight might help "headline-hunting legislators," but it unhelpfully made "lower-echelon executive officers" fear for their jobs and reputation. Party regulars were always quick to see a burgeoning state as an expansion of "one of the most concrete and tangible fighting grounds of government, namely, jobs." 33

31. Frankfurter, Public and Its Government, 151, 127-28, 133, 114, 146.

32. Ibid., 133, 135, 122, 151, 127, 153, 163; Frankfurter, "Task of Administrative Law," 618; see Roscoe Pound, "The Administrative Application of Legal Standards," Reports of the American Bar Association 44 (1919): 464-65.

33. Willard Hurst, "The Uses of Law in Four 'Colonial' States of the American Union," Wisconsin Law Review 1945: 577; Hurst, Growth of American Law, 435-36, 441, 443; Hurst to Raoul Berger, 18 November 1963, Box 1, Raoul Berger Papers, Harvard Law School Library; "Symposium on Lawyers under the United States Civil Service," American Law School Review 9 (1942): 1316. 
Hurst also agreed with Frankfurter that "the expert should be on tap, but not on top"-unless that expert was a lawyer. ${ }^{34}$ Frankfurter's notion of proper training may have been more lawyerly in its emphasis on reason, and Hurst's more social scientific in its emphasis on social function, but both believed that lawyers were peculiarly suited to seeing the complex whole that specialists missed. "The lawyer is the expert whose skill it is to make social use of the experts in all other fields," Hurst wrote in 1942. The very nature of the legal profession-"the peaceful adjustment of conflict and the co-ordination and planning of men's interrelated activities"-made lawyers "jacks-of-all-trades." 35 Together with their knowledge of "problems of power," this eclectic outlook permitted them to "mould the social environment into a decent, viable balance of power for the greater liberty of private individuals and groups." 36

Yet, if Hurst looked to Frankfurter for guidance in understanding the administrative process in its own right, he must have been disappointed. True, Frankfurter praised the Commonwealth Fund's investigations of the internal working of administrative agencies during the 1920s and 1930s. "Only a physiological study of administrative law in action will disclose the processes, the practices, the determining factors of administrative decisions, and illumine the relation between commissions and courts, now left obscure by the printed pages of court opinions," he wrote in the preface to one of them. For lawyers, however, the chief utility of such projects was the insight they provided into the task of tailoring standards of judicial review to the "history, structure and enveloping environment" of a particular agency. Here and whenever Frankfurter identified "the concern of Administrative Law" as a field, he settled not on what administrative agencies did, but on how "the traditional system of Anglo-American law and courts" disposed of the jurisdictional and constitutional issues administrative action raised. ${ }^{37}$

34. Frankfurter, Public and Its Government, 161.

35. Willard Hurst, "Legal History: A Research Program," Wisconsin Law Review 1942: 323.

36. Hurst to Mark DeWolfe Howe, 22 June 1949, Box 3, Howe Papers; Hurst, Law and the Conditions of Freedom, 42-43.

37. Frankfurter, "Task of Administrative Law," 620, 619; Frankfurter and Davison, Ad. ministrative Law, vi, v. In considering Frankfurter a key figure in the development of an administrative law that had "nothing to do with the substance of administrative decisions," I am following William C. Chase, The American Law School and the Rise of Administrative Government (Madison: University of Wisconsin Press, 1982), 14. University-based law professors ought not to bear the sole blame for this development, however. Frankfurter's project would not have succeeded had practicing lawyers not shared his fears for the independence of the legal profession. Ronen Shamir, Managing Legal Uncertainty: Elite Lawyers in the New Deal (Durham: Duke University Press, 1995). 


\section{A Seminar in Statecraft}

In the end, then, Hurst had to look beyond Frankfurter for his fullest, most satisfying insight into the work of administrators during the Depression and New Deal. He would ultimately find it as a member of the Harvard Law Review. Looking back, Hurst considered the Review very much a part of his education. In fact, law review was "the best seminar any law school offers," "an absolutely triple-A educational experience." As Note Editor he was both "merciless" and tireless. Each week would find Hurst closeted with a new author, often for many ten-hour days, as the two hammered out the "original draft together" in an intense, collaborative effort. The views expressed in the notes are as much a guide to Hurst's thinking as they are to that of their anonymous authors. ${ }^{38}$

Some of the notes Hurst edited addressed issues near the core of Frankfurter's court-centered approach to administrative law. For example, a note on Panama Refining Company v. Ryan (the so-called "Hot Oil" case) attempted to salvage something from the wreckage of the Supreme Court's attack on the National Industrial Recovery Act (NIRA) under the delegation doctrine. From the start Frankfurter had misgivings about the statute because of the danger that the National Recovery Administration would produce self-interested cartels instead of intelligently struck balances of private and public interests. Delegation was not an evil in itself, however. In fact, it was necessary if his farseeing administrators were to be free to perform their duties. ${ }^{39}$

The note on Panama Refining that Hurst edited-in all likelihood, along lines Frankfurter himself suggested-argued that even after the decision a better-crafted delegation to a more established agency would easily survive constitutional review. Judicial deference to the ICC, for example, showed that courts would uphold delegations for matters requiring prompt action, facility with complex details, and expert knowledge. Congress's delegation to the National Recovery Administration, in contrast, neither mandated the "expert handling" of matters entrusted to it nor specified the process by which that expertise would be acquired or employed. Twenty years later, Hurst would, in effect, restate this argument by characterizing Panama Refining and the Schechter decision as "reactions to pressure-group legislation, rather than as curbs on official agencies." 40

38. Hurst, Smail Interview, 6-8. I have been unable to identify the note Hurst wrote during his second year at Harvard.

39. Peter Irons, New Deal Lawyers (Princeton: Princeton University Press, 1982), 24; Nelson Lloyd Dawson, Louis D. Brandeis, Felix Frankfurter, and the New Deal (Hamden, Conn.: Archon Books, 1980), 63-70.

40. "Delegation of Power by Congress," Harvard Law Review 48 (1935): 798-806; Willard 
In other notes Hurst went beyond such Frankfurterian concerns to collaborate on studies of administrative bodies in their own right. One lengthy note, for example, reviewed the "unique body of authority on peacetime regulation of labor relations" produced under the NIRA by the first National Labor Relations Board (presided over by Hurst's future law dean, Lloyd Garrison). Even more impressive was a study of the consequences for "bodies administrative and legislative rather than judicial" of the decline in railroad revenue brought on by the Great Depression and the rise of competing modes of transportation. Other notes addressed such landmarks of the New Deal as the Public Works Administration and the Tennessee Valley Authority. ${ }^{41}$

In the "very select seminar" of the Harvard Law Review, then, Hurst at last acquired some direct insight into the working of the administrative state to complement the other lessons he was taught or taught himself at law school, such as the inherently political nature of common law reasoning, the functional origins of the administrative state, and the frailty of the delegation doctrine as an obstacle to the growth of administrative action. Once he reached the hospitable environment of Garrison's law school he would have the freedom and security to assemble a legal pedagogy and jurisprudence that responded, as he told the historian Hendrik Hartog, "to my own sense of the things that my own legal education had never given me." 42 Before doing so, he would extend his education with apprenticeships under two of the most eminent figures in American legal history. In some respects, Frankfurter and Brandeis confirmed Hurst's views about law, history, and administration; in others, they presented him with examples he would have to outgrow or, in Brandeis's case, repress.

\section{"Public Policy in the Dimension of Time"}

After his graduation and a half-hearted testing of the market for young lawyers in Chicago, Hurst returned to Cambridge to serve as Frankfurter's research fellow during the 1935-36 academic year. The fellowship, which

Hurst, "Review and the Distribution of National Powers," in Supreme Court and Supreme Law, ed. Edmond Cahn (Bloomington: Indiana University Press, 1954), 161; Schechter Poultry Corp. v. U.S., 295 U.S. 495 (1935).

41. "The Decisions of the National Labor Relations Board," Harvard Law Review 48 (1935): 630-59; "Railroad Revenue Problems As Affected by the Decline in Traffic," ibid., 1382-1400; "PWA Loans and Grants for Municipally Owned Public Utilities," ibid. 47 (1934): 89-95; "The Constitutionality of the TVA as a Power Development Program," ibid. 48 (1935): 806-15.

42. Hartog, "Snakes in Ireland," 382. 
Frankfurter financed through private fund-raising, was already a well-established stepping stone to Supreme Court clerkships with Holmes or Brandeis and a career as a law professor. The principal goal of the fellowship, as Frankfurter saw it, was "to win men of calibre for law teaching by giving them ... an apprenticeship taste of it." His success was borne out in the careers of Hurst and his predecessors, who included Paul A. Freund, Henry M. Hart, Jr., Wilber Katz, James M. Landis, David Riesman, Jr., Malcolm Sharp, and Harry Shulman. ${ }^{43}$

Hurst's principal task was to help Frankfurter prepare a series of lectures on judicial interpretation of the Commerce Clause in the nineteenth century. ${ }^{44}$ The Commerce Clause under Marshall, Taney, and Waite was Frankfurter's attempt to illustrate the subtle, ad hoc nature of constitutional development and, in the process, to advance Louis Brandeis's project of protecting the states' experiments in economic regulation from conservatives on the Supreme Court. "The states need the amplest scope for energy and individuality in dealing with the myriad problems created by our complex industrial civilization," Frankfurter had argued in The Public and Its Government. In 1934 and 1935 he used similar terms in arguing that any system of unemployment insurance enacted by Congress should defer to the existing programs of the states, such as the one Louis Brandeis's daughter and son-in-law, Elizabeth and Paul Raushenbush, had drafted for Wisconsin along lines suggested by the justice himself. ${ }^{45}$

Frankfurter's lectures showed that the Constitution, properly interpreted, did not stand in the way. The development of the Dormant Commerce Clause, in particular, was a matter of "practical necessities and shrewd judgments about practical matters," not deductions from "a technical rule of law." During its formative years the U.S. Supreme Court had weighed a variety of factors in coming to a decision in particular cases, including "state necessities, the fitness of state relief as against nation-wide action, the limited manifestation of a given evil or the limited benefits of its correction, [and] the actual interest of the whole country in a phenomenon

43. Hurst, Smail Interview, 9; Hartog, "Snakes in Ireland," 373; Circular Letter, 15 February 1937 , reel 88, FF-LC.

44. In addition, Hurst audited two courses taught by Frankfurter, a seminar on legislation co-taught by James M. Landis, and Roscoe Pound's jurisprudence seminar. Pound's course struck Hurst as "a rather fruitless enterprise" presided over by a dogmatic, isolated, and "rather arrogant" figure. Its reading list would nonetheless serve as the point of departure for Hurst's own exploration of philosophical and social scientific work relating to law. Hartog, "Snakes in Ireland," 373, 374-75, 377; Hurst, Smail Interview, 9-10; Hurst to Lloyd K. Garrison, 3 June 1946, Box 5, Garrison Papers.

45. Felix Frankfurter, The Commerce Clause under Marshall, Taney and Waite (Chapel Hill: University of North Carolina Press, 1937); Frankfurter, Public and Its Government, 48; Dawson, Brandeis, Frankfurter, and the New Deal, 103-12. 
especially virulent in a particular state." Although Frankfurter denied that the nineteenth-century cases could "be put in the categories of our own thought," the "dispassionate verdict of history" he announced looked toward greater freedom for the states. ${ }^{46}$

During the fall of 1935 and most of the winter, Hurst conducted the research for the lectures with little guidance from Frankfurter. "My chore for him for that year was to bury myself in all the material I could find" about the Supreme Court and the Commerce Clause between 1789 and 1890. In December, Hurst submitted a tentative outline, an analysis of the relevant cases, and a list of the materials he had consulted. He offered the last, he explained, "Not as a Little Jack Horner gesture, or to show the extent of the investigation, so much as to bring out its limitations." The list was impressive, but the original sources were, as Hurst observed, "all primarily legal," and he stuck close to constitutional historians-Charles Beard, Albert Beveridge, James Bradley Thayer, and Charles Warren-for "the general political and social atmosphere of the time."

He then typed lengthy memoranda outlining successive phases in the development of the law. These did not amount to "a rough draft" of the three lectures, Hurst insisted, but they did serve as the principal basis for the remarkable two-week "seminar" Frankfurter conducted at his home on Brattle Street in early 1936, from which the manuscript emerged. "He'd pace the floor and talk, and when he said what he thought was the right way to grab the thought he had in mind I'd knock it off on the typewriter," Hurst recalled. Then Hurst would subject Frankfurter's text to a "very real, give-and-take criticism." "If I thought he wasn't getting the proper emphasis or was not getting the proper material out of the case," he explained, "I was supposed to barge in and argue with him." Given this approach, the relative contributions of Hurst and Frankfurter to the finished work are difficult to untangle from the surviving documents in Frankfurter's papers, but that record is consistent with both Hurst's claim that Frankfurter "put himself into what he wrote" and Frankfurter's acknowledgment of "the indispensable collaboration of Mr. Willard Hurst." 47

Frankfurter took away from the experience a lasting belief in Hurst's

46. Frankfurter, Public and Its Government, 74, 77-78; Frankfurter, Commerce Clause, $10,112$.

47. Hurst, Smail Interview, 10-1 1; Frankfurter, Commerce Clause ("Acknowledgments"); see also Hartog, "Snakes in Ireland," 373. Frankfurter and Landis produced The Business of the Supreme Court: A Study in the Federal Judicial System (New York: Macmillan, 1927) through a similar collaboration, although, as Stanley Kutler has suggested to me, Hurst never addressed Frankfurter with the sycophancy of Landis and other protégés. Donald A. Ritchie, James M. Landis, Dean of the Regulators (Cambridge, Mass.: Harvard University Press, 1980), 21-22. 
abilities. In the early months of 1937 , he urged Dean Acheson to take the young Brandeis clerk under his wing. "I wonder if you have had a chance to penetrate beneath the surface of his shyness and social inexperience," Frankfurter wrote. "He is really an unusual fellow-a man of uncommon culture, refinement and maturity, but he ought to have more experience of the world than his devotion to his duties and his newness in Washington are likely to afford him." Less than a week later he again praised Hurst to Acheson: "Hurst is one of those rare creatures who does not need the seasoning that practice sometimes gives. As Marion said to me when he was here last year, 'Hurst is mature enough now to go on the bench."' And, in commending Hurst to Lloyd Garrison, Frankfurter exclaimed, ${ }^{48}$

I cannot speak too highly of his scholarly equipment, his penetrating mind, and the kind of integrity which suffuses the whole quality of a man's work and makes the difference between a teacher who imparts ferment and just a grubbing pedant. He is a shy, modest fellow, but a man of real firmness of character which is bound to leave its impress, by its intrinsic force, upon students, colleagues, and the community. Grab him if you can!

\section{Beyond Originalism}

The fellowship had two significant consequences for Hurst, one lasting, the other of shorter duration. First, Hurst left the fellowship with an understanding of constitutional history that all but incapacitated him as a producer of originalist arguments in constitutional litigation. In the lectures on the Commerce Clause Frankfurter stressed the historically contingent content of the Constitution and the corollary that past meanings could be revised in light of subsequent developments. "The Constitution of the United States is most significantly not a document but a stream of history," Frankfurter declared. He also quoted Holmes to argue that although history played a critical role in constitutional law-it "sets us free and enables us to make up our minds dispassionately"-it was not filled with authoritative commands to the present. ${ }^{49}$

Hurst reached a similar conclusion early in his research assistantship. In 1934 a New Deal lawyer, Robert L. Stern, argued in the Harvard Law Review that the unambiguous intent of the Framers in drafting the Commerce Clause was to check one state's infliction of injustice upon another, and not to constrain the federal government. The article quickly became a touchstone for New Dealers' efforts to expand the reach of the federal

48. Frankfurter to Acheson, 7, 12 May 1937, reel 11, FF-LC; Frankfurter to Garrison, 27 February 1937, Box 192, FF-HLS. The "Marion" to whom Frankfurter referred in the preceding sentence was his wife, Marion Denman Frankfurter.

49. Frankfurter, Commerce Clause, 2. 
government, a goal that Hurst almost certainly supported. Nonetheless, Hurst objected that the meaning of the Commerce Clause should not be confined to the intent of the Framers. As Hurst put it, the clause should be understood "as a matter of history rather than of dialectic." Because Stern conceded that the "national powers should be what they were intended to be in 1787," he was obliged to exaggerate the economic nationalism of the Framers. He would have done better to have shown what the powers of the national government "were then intended to be, in order that it may more vividly be seen what they have become." 50

Hurst expressed similar views in a conference held at the New York University School of Law in 1953. Where a constitutional question involved "the definition of particular legal agencies or particular legal procedures," the words had "a precise, history-filled content" that judges had to respect. But in considering "grants of substantive power to be used in an indefinite future," judges needed to regard "the general political, economic, and social history of the United States" in the intervening years. To illustrate the proper interpretation of such general grants, Hurst referred to a favorite decision from Frankfurter's Commerce Clause book, Pensacola Telegraph Co. v. Western Union Telegraph Co., in which Chief Justice Waite updated earlier doctrine in light of the recently perfected technology of telegraphy. He also invoked Holmes's view, in Missouri v. Holland, that "our whole experience," and not merely "what was said a hundred years ago," was relevant to constitutional interpretation. To hold otherwise, Hurst believed, was to attempt to "evade the responsibilities of choice which resistless change will surely thrust upon" the present. ${ }^{51}$

Hurst acknowledged that empowering judges to consult "general history, as compared with the history crystallized in particular decisions or authoritative documents," would expand their discretion, but he denied that objectivity or responsibility in judging would suffer as a result. Properly trained lawyers could help judges recover the historical record, "not just as it is read by any one mind or even any one generation, but as it emerges in many-sided reality from the best consensus of many minds and many years." Astute judges could reach the decision that best addressed the social needs revealed through this inquiry. Thus, in Pensacola, "hardheaded, fact-minded Waite looks at the way contracts are made, goods ordered and shipped, government administered at a distance, for his conclusion

50. Willard Hurst, "Notes on the History of the "Commerce Clause," [1935], reel 136, FF-LC; see Robert L. Stern, "That Commerce which Concerns More States than One," Harvard Law Review 47 (1934); 1335-66; Irons, New Deal Lawyers, 48.

51. Willard Hurst, "The Process of Constitutional Construction: The Role of History," in Supreme Court and Supreme Law, 57, 56, 58; Pensacola Telegraph Co. v. Western Union Telegraph Co., 96 U.S. 1 (1877); Missouri v. Holland, 252 U.S. 416, 433-34 (1920). 
that history has brought the telegraph into the mainstream of interstate commerce." 52

Hurst's understanding of the past was too complex, its meaning too open to debate, for most constitutional litigators, who looked to history for a single, authoritative, and unambiguous "original understanding" with which to constrain judicial discretion. The appendix on the history of treason Hurst prepared over the winter of 1944-45 for the government's brief in Cramer v. United States remains a leading treatment of the subject, yet the Supreme Court lawyer Frederick Bernays Wiener complained that, by trading advocacy for objectivity, it weakened the prosecutors' case..$^{53}$ In the $1950 \mathrm{~s}$, a sympathetic Hurst tried to help the NAACP in Brown v. Board of Education by reviewing the history of the ratification of the Fourteenth Amendment in Wisconsin. Wisconsinites endorsed "equality of treatment before the law," Hurst explained to William T. Coleman, but their views were "logically compatible with segregation." "Nothing in the Wisconsin materials seems to me to bear directly on the separate-but-equal position." Still, Hurst believed that history had something to offer the NAACP's case. Because the Equal Protection Clause was an open-ended standard, he told Thurgood Marshall, it should be interpreted in light of changing historical circumstances. "Matters which did not seem of prime public concern, or perhaps not of public concern at all, in one social environment, may, in the unfolding of a new environment, take on [a] wholly different complexion." That explained why Chief Justice Waite expanded the reach of the Commerce Clause in the Pensacola case, Hurst told Marshall, and that, he implied, was why the Supreme Court should find new meaning in the Equal Protection Clause. ${ }^{54}$

52. Hurst, "Role of History," 58.

53. James Willard Hurst, The Law of Treason in the United States (Westport, Conn.: Greenwood Publishing, 1971); J. Woodford Howard, Jr., "Advocacy in Constitutional Choice: The Cramer Treason Case, 1942-1945," American Bar Foundation Research Journal 1986: 399. For the timing of Hurst's work on the appendix, see "Willard Hurst," Box 7, Subject Files, WLS-UWA; Lloyd K. Garrison to Oliver Rundell, 20 September 1944, Box 55, Series 11 / 1/1, University of Wisconsin Archives, Memorial Library, Madison (hereafter General Correspondence, WLS-UWA).

54. Hurst had the research assistance of Herbert Gutman, later an eminent historian of the American working class, but at the time a graduate student in Wisconsin's history department. Hurst to William T. Coleman, 28 July 1953, Accession M81-487, State Historical Society of Wisconsin, Madison; Hurst to Thurgood Marshall, 5 November 1953, Box 1, Accession 81/73, University of Wisconsin Archives, Memorial Library, Madison (hereafter JWH-UWA). On the NAACP lawyers, the historians, and Brown v. Board of Education, see Richard Kluger, Simple Justice (New York: Alfred A. Knopf, 1976), 618-26, 634-41; Mark V. Tushnet, Making Civil Rights Law: Thurgood Marshall and the Supreme Court, 19361941 (New York: Oxford University Press, 1994), 196-200. 


\section{Beyond the Judicial Process}

On the question of the value of history to constitutional interpretation, then, Hurst did not stray far from the position he held as Frankfurter's research fellow, which was quite close to his mentor's own view. But in regard to their mutual fascination with the history of the U.S. Supreme Court, the two men ultimately parted company. Hurst first encountered Frankfurter's captivating historical approach to the Court in courses on federal jurisdiction and public utilities law. "He would just squeeze so much out of" a case, Hurst recalled. Frankfurter's fascination with the Supreme Court was infectious, and, thanks to the research assistantship, Hurst got a larger dose of it than most of the professor's many protégés. He would need several years of law teaching half a continent away from Cambridge before he could envision an alternative to his mentor's court-centered legal history. ${ }^{55}$

Frankfurter's continuing influence was evident in Hurst's first legal history course, the seminar with Hesseltine on the history of the U.S. Supreme Court, and in a series of book reviews published in 1938 and 1939, in which Hurst pilloried histories of the Court, biographies of its justices, and a handbook of constitutional history for, in effect, ignoring the concerns that animated Frankfurter. The handbook, for example, in Hurst's judgment overlooked "the economic and social conflicts which find expression in constitutional doctrine" and the "matters of procedure and of technique in advocacy and decision" that constrained the justices' decision making. ${ }^{56}$

At some point in the late 1930s, Hurst struck out in a new direction. ("I didn't wanted to wind up knowing nothing except all the gossip about the judges," he later explained.) The impetus was his development, between 1938 and 1940, of an ambitious course on public policy toward injuries in the workplace, which took as its starting point a more modest set of materials Garrison assembled before Hurst's arrival. Hurst and Garrison wanted the "Law in Society" course to "expose students to a much broader range of legal agencies than just courts. We wanted something that would involve the development of legislation and administrative law particularly." That it did, first by tracing a single case through the legal process and then by retracing the development of the law of workplace injury from its common law origins through the triumph of worker's compensation. "I already was

55. Hartog, "Snakes in Ireland," 373, 377.

56. Hurst to Frankfurter, 27 September 1938, Box 192, FF-HLS; Willard Hurst, review of Handbook of American Constitutional Law, by Henry Rottschaefer, Harvard Law Review 53 (1939): 350-51. See also Willard Hurst, review of The Life of John McLean, by Francis P. Weisenburger, Harvard Law Review 5I (1938): 1306-10; Willard Hurst, review of $M r$. Justice Miller and the Supreme Court 1862-1890, by Charles Fairman, Columbia Law Review 40 (1940): 564-71; Hartog, "Snakes in Ireland," 376. 
in legal history more or less with that course," Hurst recalled. "Law in Society" was "a history course," but "not in any antiquarian sense." Rather, it was a study of "the development of public policy in the dimension of time."s

Early in 1940, Hurst reported to Frankfurter on his plans for a "'large canvas legal history." That autumn, as he was readying requests for permission to reprint material for "Law in Society," he also received Justice Brandeis's approval of his "thrilling" plans for "an intensive study of Wisconsin's economic-legal history." By 1941 students working under his grant from the National Youth Administration had compiled a digest of the decisions of the Wisconsin supreme court in terms of the industries out of which the cases arose. Hurst settled upon the lumber industry after a revelatory encounter with the environmentalist Aldo Leopold at a university dining club. He made some "test soundings" before leaving for Washington and the Board of Economic Warfare in February 1942. In 1942 he published a research agenda that took social function, not doctrine, as its organizing principle. "The more we examine law not in terms of doctrinal classification, but in terms of a given economic or cultural function or activity upon which it plays from all sides," he concluded, "the more we may learn about the wise choice of regulations, the more broadly we may appraise accomplishments and plan for the future." 58

As readers of his later work know well, Hurst's aspirations for a legal history that comprised the administrative and legislative processes as well as litigation survived his "limited experience as a bureaucrat" during World

57. Hartog, "Snakes in Ireland," 377; Hurst, Smail Interview, 25, 23-24, 20. On the "Law in Society" course, see William N. Eskridge, Jr., "Willard Hurst, Master of the Legal Process," Wisconsin Law Review 1997: 1181-89, and Ernst, "The Ideal and the Actual in the State." Hurst insisted that he and Garrison "framed it together." Garrison thought otherwise. "Law in Society is really a most interesting course," Garrison wrote to David Riesman, Jr., in a vain attempt to lure him to Wisconsin, "and I can say this without immodesty, since my own contribution to it in the way of material has been very minor, and the big job has been done by Hurst." In 1960 Garrison refused a share of the royalties when Carl Auerbach and Samuel Mermin published a revised edition. "My own contribution to the book was minimal at the outset, except in terms of enthusiasm; the basic ideas were Willard's, and I did no more than fill in a few chinks." Hurst, Smail Interview, 20; Garrison to Riesman, 26 May 1942, Box 54, General Correspondence, WLS-UWA; Garrison to Carl A. Auerbach, 18 April 1960, Box 5, Garrison Papers.

58. Frankfurter to Hurst, 17 April 1940, reel 39, part 3, FF-HLS; Brandeis to Hurst, 19 October 1940, reel 33, LDB-HLS; Hurst to Thurman Arnold, 4 November 1940, Thurman Arnold Papers, American Heritage Center, University of Wyoming, Laramie; James Willard Hurst, comp., "A Digest of Regional Sources for the Study of the Economic and Political History of the Law: Volume One: The Wisconsin Reports, 1 Pinney (1839) through 235 Wisconsin (1940)" (N.p., 1941); Hurst to Dan Dykstra, 7 April 1953, Box 1, JWH-UWA; Hartog, "Snakes in Ireland," 379; Hurst to Garrison, 10 August 1945, Box 57, General Correspondence, WLS-UWA; Hurst, "Research Program," 325, 329. 
War II. Hurst would take almost two decades after his demobilization to publish his great exemplar of the functional approach to law, Law and Economic Growth, but the extent to which his views on legal history had departed from those of his mentor was obvious as early as 1955 . When Frankfurter sent Hurst a reprint of his contribution to the Harvard Law School's conference on the bicentennial of John Marshall's birth, the onetime student replied to his old professor that he hoped Harvard might "stir itself once in a while in coming years . . to acknowledge the existence of other processes of government" than the judicial. "We continue to be a very litigious-process-biased group of legal scholars," he continued, "and I am discouraged at the scant signs among the newest generation of law teachers of any large amount of interest in venturing into more original research in the legislative and administrative fields." The Harvard Law School would have done better to sponsor a conference on "the chief executive as law maker" or celebrate the work of a great governor, like Al Smith of New York. If the justice's response to this suggestion, made at the dawn of the Warren Court, ever took written form, it does not, apparently, survive. ${ }^{59}$

\section{Isaiah's Apprentice}

After his year with Frankfurter, Hurst embarked on a second "working partnership," this time with "an aged master of the craft." As a rule, relations between the eighty-year-old Justice Brandeis and his twenty-six-year-old clerk were formal and businesslike, thanks to the justice's "jealous guardianship of his own privacy." Personal exchanges, if few, were among Hurst's most treasured memories. One was Brandeis's confiding remark, in the midst of the Court-packing controversy, that FDR was too much the "smart man," who short-sightedly grasped at an immediate political victory to the longterm detriment of governmental institutions. Another was the justice's verdict on Woodrow Wilson's doomed campaign for the League of Nations: it showed "the ever-present need that men be conscious of the limits of their physical, moral and mental energy, and not overcommit themselves." A third was Hurst's Thanksgiving dinner with Brandeis, where the guests included Justice Benjamin Cardozo, the social reformer Monsignor John Ryan, and Frankfurter's model administrator, Joseph Eastman. ${ }^{60}$

59. Hurst to Mark Howe, 1 January 1953, Box 3, Howe Papers; Hurst to Frankfurter, 18 October 1955, reel 42, FF-LC; Frankfurter, "John Marshall and the Judicial Function," in Of Law and Men: Papers and Addresses of Felix Frankfurter, 1939-1956 (New York: Harcourt Brace, 1956), 3-30.

60. Hurst, Smail Interview, 15; Hurst to Alpheus Thomas Mason, 3 November 1941, quoted in Mason, Brandeis: A Free Man's Life (New York: Viking Press, 1946), 643; Hurst to 
Like other Brandeis clerks, Hurst did most of his work for the justice in one of the two apartments Brandeis rented on California Street north of Dupont Circle, except for occasional research trips to the Supreme Court or the Library of Congress. "At the start of the year, just to get me into the swing of things and keep me busy," Hurst wrote short memoranda on petitions for certiorari. The bulk of his work, however, was to assist Brandeis in completing opinions the justice had already drafted. Hurst's job was to check Brandeis's statement of the facts of the case against the record, find precedential or statutory authority for any unsubstantiated legal claim, and generally to "argue with him wherever I found anything that I felt called for arguing." 61

Brandeis did set limits on Hurst. He was not free to raise "points of academic interest," Hurst recalled, and once, when he wrote a "hot little piece" urging Brandeis to vote to take up an immigration case in which an "obvious injustice had been done," the justice adopted a "rather hard-boiled attitude" and lectured him that the Supreme Court could only consider cases presenting broad issues of public policy. When Hurst could not find an authority for Brandeis's claim in Senn that the "freedom of speech ... guaranteed by the Federal Constitution" extended to unions' publicizing the facts of a labor dispute, Brandeis simply smiled and replied, "I think we'll let it stand anyway." David Riesman, Jr., Brandeis's clerk during the preceding year, had a similar experience. "We have had several good scraps about policy," Riesman wrote to Frankfurter in November 1935, "but remembering your warning, I don't push him when I see his mind is made up-as it generally is."'62

Within limits, then, Hurst felt as free as if he "were back at the Harvard Law Review, editing some piece of writing" by one of his classmates. In one case the young man suggested that Brandeis should not "so baldly" claim that a precedent had been overruled; in another he drew the justice's attention to "a rather ambiguous" use of a word; in a third he observed that "a bit more charity" was in order in describing the actions of a district judge, "in view of the slightly dubious virtue" of the Court's own resort to

Charles E. Wyzanski, 20 March 1954, Box 1, JWH-UWA; Hurst to Frankfurter, 20 December 1955, reel 42, FF-LC. I am grateful to Alfred S. Konefsky for drawing my attention to Hurst's communication with Mason.

61. Hurst, Smail Interview, 13, 14-15. On Brandeis and his clerks, see Philippa Strum, Louis D. Brandeis: Justice for the People (Cambridge, Mass.: Harvard University Press, 1984), 354-61.

62. Hurst, Smail Interview, 15, 13-14; Senn v. Tile Layers Protective Union, 478; Hurst to Philippa Strum, 3 October 1980, quoted in Strum, Justice for the People, 360-61; Riesman to Frankfurter, 21 November 1935, quoted in Dawson, Brandeis, Frankfurter, and the New Deal, 131. 
a per curiam opinion. Hurst even offered Brandeis grammatical advice, albeit "with humility." 63

Once again, Hurst impressed a mentor. "You cannot be unaware of the fact that you are giving the Justice help and comfort," Frankfurter wrote to Hurst in October 1936. In fact, Hurst worked so hard that the justice became concerned. "You are making good progress," Brandeis assured him in January 1937. "Don't fail to get adequate sleep within the next 24 hours." In May, Frankfurter could report to Dean Acheson that the justice considered Hurst "the best secretary, professionally speaking, he has ever had." 64

\section{The Presumption of Constitutionality}

Hurst was convinced that he had witnessed a "constitutional crisis" in the years 1936 and 1937 when a majority of the Court clashed with "a confused and troubled general public hit by the depression." The end of the crisis came with a "breakthrough" in public policy, the Court's unambiguous decision to presume the constitutionality of statutes and administrative decisions regulating economic interests. Hurst thoroughly approved of the "presumption of constitutionality," and it became an abiding concern of his teaching and writing. 65

For Hurst, the rule that "a statute is constitutional until a challenger plainly shows the contrary" was much more than a rhetorical flourish. Properly understood, it was "a somewhat complex structure" that effectively prevented the judiciary from questioning the facts and "fact-enmeshed values" found by legislatures and administrators. The presumption put a heavy burden of proof on the party challenging a statute or regulation. "The at-

63. Hurst, Smail Interview, 15; "No. 40, Atlantic Refining Co. v. Commonwealth of Virginia (Sup. Ct. App. Va., 1936), Due Process and Commerce Clause Issues since Cudahy Packing Co. v. Hinkle, 278 U.S. 460," n.d., 2, reel 27, LDB-HLS; "No. 32, Duke Power Co. v. Greenwood County (C.C.A. 4th), Re. draft of opinion," 28 November 1936, 1, reel 25, ibid.; "No. 32, Duke Power Co. v. Greenwood County (C.C.A. 4th), Re. draft of Per curiam opinion," 10 December 1936, 2, ibid.; "No. 22, State Board of Equalization vs. Young's Market Co., Re. Draft of opinion," n.d., 2, reel 26, ibid.

64. Frankfurter to Hurst, 22 October 1936, reel 39, FF-HLS; L. D. B. to W. H., 17 January 1937, reel 27, LDB-HLS; Frankfurter to Dean Acheson, 12 May 1937, reel 11, FF-LC. The qualification-“professionally speaking"-may indicate that Brandeis thought Hurst was less adept at his famous "teas" than his more socially assured predecessors-such as Acheson-had been. On the teas, see Strum, Justice for the People, 362; Bruce Allen Murphy, The Brandeis/Frankfurter Connection: The Secret Political Activities of the Supreme Court Justices (Garden City, N.Y.: Anchor Press, 1983), 120-23.

65. Hurst to Robert W. Gordon, n.d. This document is among papers in the possession of Arthur F. McEvoy, the J. Willard Hurst Professor of Law and History at the University of Wisconsin-Madison Law School. Hereafter I refer to these papers as JWH-AFM. I am grateful to Professor McEvoy for permission to examine them. 
tacker must establish either that the legislators could not reasonably find facts to exist creating the problem with which the statute purports to deal, or that they could not reasonably determine that the statute represents a socially acceptable value or a means calculated to achieve that value." By taking "judicial notice" of facts not appearing in the record, sympathetic judges could help attackers overcome the burden, but Hurst thought they should do so only if the matter was "beyond reasonable dispute by men knowledgeable in the field." 66

Hurst often associated the presumption of constitutionality with Brandeis, who had memorably stated it in $O^{\prime}$ Gorman \& Young, Inc. v. Hartford Insurance Co. (1931) and, in dissent, in New State Ice Co. v. Liebmann (1932). ${ }^{67}$ In a tribute to Brandeis in 1966, for example, Hurst spoke of the justice's "regular, realistic search for facts" as he reviewed the ends and means of legislation. His fastidiousness in doing this, Hurst maintained, was a sign of Brandeis's "stern self discipline." Like other admirers of Brandeis, Hurst could cite many cases in support of his portrait of the justice as a proponent of judicial restraint. Yet Hurst could also recall cases in which he was more eager than his justice to promote the growth of "something like an area of prerogative power" among administrators and executive officials. ${ }^{68}$

Hurst might have cited Bourjois, Inc. v. Chapman to illustrate Brandeis's deference to a regulatory initiative. In this case the plaintiff challenged Maine's scheme of licensing the sale of cosmetics as a burden on interstate commerce. After a year's study of the Dormant Commerce Clause with Frankfurter and armed with Brandeis's opinions on the presumption of constitutionality, Hurst made short work of the issue. First he observed that the plaintiff had challenged the statute before it went into operation. After reviewing the case law, he concluded that "the statute does not on its face impose unreasonable and excessive fees." To that extent, at least, it was not a direct burden on interstate commerce. Should Brandeis go further and

66. James Willard Hurst, Dealing with Statutes (New York: Columbia University Press, 1982), 88, 89, 95; Hurst, "Legal Elements," 55, 51.

67. O'Gorman \& Young, Inc. v. Hartford Ins. Co., 282 U.S. 251 (1931); New State Ice Co. v. Liebmann, 285 U.S. 262, 280-311 (1932) (Brandeis, J., dissenting). Hurst included both cases in Willard Hurst, Some Problems in the Relationship of the Legislative and Judicial Processes (Madison: College Typing Co., 1938).

68. Willard Hurst, "A Tribute," 28 January 1966, in Student Bar Association, University of Louisville, School of Law, Fiftieth Anniversary Convocation of Justice Brandeis's Appointment to the Supreme Court of the United States (Louisville, Ky.: University of Louisville School of Law, 1966), 2; Hurst, Growth of American Law, 399-400. Neither West Coast Hotel Co. v. Parrish, 300 U.S. 379 (1937), nor NLRB v. Jones \& Laughlin Steel Corp., 301 U.S. 1 (1937), was assigned to Brandeis, and so Hurst had no occasion to prepare memoranda on these celebrated cases of judicial deference to legislatures. 
consider the actual operation of the licensing scheme since the start of the suit? No, said Hurst. Under the presumption of constitutionality, the challenger in some future attack on the statute was responsible for gathering that evidence. "This Court may not go beyond the record and take judicial notice of the operation of the Act since the hearing." On this issue Brandeis's opinion generally followed Hurst's reasoning. ${ }^{69}$

On at least three other occasions, however, the two men disagreed, with Hurst inclining toward greater freedom for administrators and Brandeis toward sustaining the superiority of the judiciary. Because Hurst worked within limits set by his "master," some of these disagreements must be inferred from subtle differences of treatment. The Bourjois case provides one example. The plaintiff had argued that, by failing to provide applicants with a hearing before a denial of a license, Maine had violated constitutional guarantees of due process. Hurst advised Brandeis to write that hearings were never necessary if applicants could obtain judicial review of administrative decisions. This went too far for Brandeis. He kept open the possibility of a future constitutional challenge to other statutes by adding the words "under the circumstances and of the character here involved" to those Hurst proposed..$^{70}$

In a second case, Brown \& Sons Lumber Co. v. Louisville \& Nashville Railroad Co., Brandeis vigorously attacked the settled practice of an administrative agency, while Hurst did what he could to limit the holding. The case was a suit filed by two shippers to recover damages from railroads that had charged them in excess of the rate specified by the "Combination Rule" of the Interstate Commerce Commission. The rule directed railroads to use a special formula in calculating freight rates whenever the Commission had not published a through rate for at least one route between two points. In seeming conflict with the language of the rule, the ICC had long construed it to apply when it had published a through rate over one or more routes, but not over the particular route a shipment would take.

The shippers argued that the federal courts had to accept the ICC's construction of the rule because it involved "the exercise of sound administrative discretion as to technical and intricate matters of tariff application and the relation of tariffs to one another," but Brandeis disagreed. The disputed language of the Combination Rule-"where no published through rates are in effect from point of origin to destination"-was "not techni-

69. “No. 534, Bourjois, Inc. v. Chapman (D. Me. 1936), Re. draft of opinion,” 6 April 1937, reel 25, LDB-HLS. Hurst also turned back the objection that the statute improperly delegated legislative power to establish rules and regulations. After surveying decisions on the regulation of lobster fishing, motor buses, and plumbing fixtures, he concluded that "delegation is as much an accepted thing in Maine today as anywhere else." Ibid., 17-18.

70. Ibid., 22; "No. 534," n.d., 4, ibid.; Bourjois, Inc. v. Chapman, 301 U.S. 183, 189 (1937). 
cal," he replied. Its interpretation was "a question of law, not differing in character from those presented when the construction of any other document is in dispute." If the ICC wanted to lower rates over the routes in question, it should hold hearings and establish a joint through rate, as the Interstate Commerce Act provided. ${ }^{71}$

Most of Hurst's memo on the case helped Brandeis sharpen or substantiate his argument, but at the end he raised a query. Should not Brandeis distinguish Brown from another case, cited by the shippers, which held that constructions of a statute by the body charged with enforcing it must be read into the statute if the construction was "not plainly erroneous," had "long obtained in practical execution," and had "been impliedly sanctioned by the reenactment of the statute without alteration in the particulars construed"? As Hurst would observe in The Growth of American Law, the emergence of such doctrines was a precondition for the development of an administrative "prerogative." Brandeis's holding ran against this trend. In 1936, to limit the damage, Hurst proposed that Brandeis declare that the ICC's construction was "plainly erroneous" and expressly note that the case involved "nothing as authoritative over the Court as intervening acquiescence by the legislature." Again Hurst's efforts proved unsuccessful. Brandeis's opinion in Brown in no way acknowledged Hurst's suggestion. ${ }^{72}$

In a final case the conflict between master and apprentice was explicit and squarely involved the presumption of constitutionality. Thompson $v$. Consolidated Gas Utilities Corporation was a challenge by one group of natural gas companies located in the Texas Panhandle to an order of the state's Railroad Commission that favored another. Both groups produced "sweet" gas, which was relatively free of sulfur and usable in heating and lighting, unlike high-sulfur "sour" gas, which was usable only for the making of carbon black, a residue left after burning gas, used in the production of paint and rubber. ${ }^{73}$ The first group owned or controlled pipelines that permitted them to deliver gas directly from their wells to consumers. Unlike these "integrated" companies, the second group-the "independents"- had no access to pipelines. The only profitable use of the gas they pumped was to "strip" it of its gasoline content and sell the residue to pro-

71. Brown \& Sons Lumber Co. v. Louisville \& Nashville R.R. Co., 299 U.S. 393, 398, 397, 400 (1937).

72. "No. 100, W.P. Brown \& Sons Lumber Co. v. Louisville \& Nashville R.R. Co. (C.C.A. 6th 1936): Re. draft of opinion," 27 December 1936, 3, reel 25, LDB-HLS; New York, New Haven \& Hartford R.R. Co. v. Interstate Commerce Commission. 200 U.S. 361, 401-402 (1906); Hurst, Growth of American Law, 399-400.

73. I am grateful to Professor Christopher J. Castaneda of the History Department at the California State University at Sacramento for insights into Texas's natural gas industry in the $1930 \mathrm{~s}$. 
ducers of carbon black. In the process they wasted a significant amount of the gas in the subterranean field. ${ }^{74}$

In 1935 the Texas legislature prohibited the use of sweet gas for the production of carbon black. It also authorized the Railroad Commission to prorate the production of natural gas in order to (1) prevent waste; or (2) adjust "the correlative rights and opportunities of each owner of gas in a common reservoir." Citing this authority, the commission ordered the integrated companies to produce significantly below the levels required to meet their existing contracts with their customers. The integrated companies could have easily met their commitments with gas pumped from their own wells, but, thanks to the order, they were forced to buy gas from the only other readily available source, the independents. The integrated companies were thus required to pay the independents for gas they would not have needed but for the proration order. ${ }^{75}$

Had the case not involved an administrative body but merely a judicial or legislative reallocation of property rights, Brandeis might not have objected. After all, in International News Service v. Associated Press, Brandeis had turned aside a natural rights claim to property in the news with the observation that property rights were a creation of the legal order. He even ventured the suggestion that a legislature might declare newspapers businesses affected with a public interest. And in Pennsylvania Coal Co. v. Mahon, Brandeis voted to uphold a statute forbidding coal companies from causing the subsidence of surface land, even when the companies had purchased the surface owner's right of support. ${ }^{76}$

But Thompson reached the Court after Brandeis had become alarmed by the growth of administrative power under the National Industrial Recovery Act and other New Deal statutes. In his dissent in New State Ice he had warned that such measures might make excessive demands "upon the human intelligence and character of men," and with his vote in Schechter Poultry Corp. v. United States he struck at the public cartelization of industry. Finding in Thompson that the public allocation of market share had survived $S$ chechter, he reacted with a vehemence more commonly associated with one of the Four Horsemen. "Our law reports present no more glaring instance of the taking of one man's property and giving it to another," Brandeis thundered. ${ }^{77}$

74. Thompson v. Consolidated Gas Utils. Corp., 300 U.S. 55, 58-61 (1937).

75. Thompson v. Consolidated Gas Utils. Corp., 63, 78.

76. International News Serv. v. Associated Press, 250, 267 (Brandeis, J., dissenting); Pennsylvania Coal Co. v. Mahon, 260 U.S. 393, 416-22 (1922) (Brandeis, J., dissenting).

77. Schechter Poultry Corp. v. United States; Dawson, Brandeis, Frankfurter, and the New Deal, 129-30; Thompson v. Consolidated Gas Utils. Corp., 79. 
At first Brandeis wanted to attack the order on statutory grounds and avoid a constitutional holding, as had the district judge who originally heard the case. Arguing that the statute authorized proration only to prevent waste and that the commission had not shown that the integrated companies had wasted gas, the judge concluded that the commission's order was ultra vires and void. Such reasoning would permit Brandeis to hamstring the Railroad Commission without explicitly rebuking the Texas legislature.

Hurst would have nothing of it. Presumably he preferred a statutory holding to a constitutional one as the more easily surmountable barrier for the administrative state, but he was convinced that there was no factual support for the district judge's reasoning in the legislative record. He showed Brandeis that the Texas legislature had authorized the proration scheme to go beyond the common law in protecting the independents' interest in subterranean gas and to compensate them for revenue lost as a result of the ban on producing carbon black. The proration scheme was "part of a general plan to combat waste with what the legislature conceives [as] fairness to all sides," Hurst insisted. It mixed "the idea of waste prevention and adjustment of rights of pool-owners in inextricable fashion." He concluded, "I do not believe the orders can fairly be called ultra vires even by the construction-which-will-avoid-grave-constitutional-doubts incantation."78

Brandeis was slow to surrender this line of argument, and on December 17 he returned the memorandum setting out Hurst's views and instructed his law clerk to study the legislative history again. Hurst replied later the same day that "another period of reflection on the statute leaves me still unregenerate." He observed Christmas by writing two memoranda on the case. One showed that the Texas legislature had established similar policies for the oil industry in order to "open up the pipe line companies" markets to the independents." Another surveyed Texas cases on the regulation of motor carriers, the spacing of wells, the location of high schools, the valuation of property for tax purposes, and the closure of roads to establish that the findings of the Railroad Commission were reviewable only under the relatively deferential "substantial evidence" standard and that they were not subject to de novo review. ${ }^{79}$

78. "No. 89, Thompson et al., R.R. Comm. of Texas v. Consolidated Gas Utilities Corp. (W.D. Tex. 1936): Re. Construction of Statute," 17 December 1936, 3, 4, 5, 4, reel 26, LDBHLS.

79. WH, untitled memorandum, 17 December 1936, ibid.; "No. 89, Thompson et al., R.R. Comm. of Texas v. Consolidated Gas Utilities Corp. (W.D. Tex. 1936), Re. history of oil proration in Texas," 25 December 1936, 4, ibid.; "No. 89. Thompson et al., R.R. Comm. of Texas v. Consolidated Gas Utilities Corp. (W.D. Tex. 1936): Re. Texas law on review of administrative findings," 25 December 1936, ibid. In an earlier memorandum Hurst observed 
After a meeting on January 7, Brandeis finally conceded Hurst's point. But rather than uphold the statute under the presumption of constitutionality, as perhaps Hurst believed he would, Brandeis resolved to strike it down on constitutional grounds. True, the justice wrote in his opinion, "all administrative regulations purporting to be made under authority legally delegated" enjoyed the benefit of "a presumption of the existence of facts justifying the specific exercise" of legislative power. The proration order would nonetheless be unconstitutional if "shown to bear no reasonable relation either to the prevention of waste or the protection of correlative rights, or if shown to be otherwise arbitrary." In Thompson, Brandeis concluded that the integrated companies had sustained "the heavy burden of overcoming the presumption and of establishing that the order is an arbitrary taking of their property." 80

In fact, the plaintiffs succeeded less from their own efforts than from the ingenious reading of the record that Hurst dutifully produced for Brandeis, who incorporated it into his decision. That Hurst had not succeeded in convincing himself became clear later in the term in a separate case challenging the statute's ban on the use of sweet gas to produce carbon black. Brandeis voted to uphold the ban, leaving it to his clerk to explain why the presumption of constitutionality had not been overcome in that case as well. After proposing language that turned aside the plaintiff's argument, Hurst declared himself "a bit troubled as to whether this skeptical treatment" was consistent with Thompson. Brandeis, evidently, was not. "No facts have been found, or established by evidence, which would justify us in pronouncing the action of the Legislature arbitrary," he flatly wrote. ${ }^{81}$

The Thompson decision was troubling for anyone inclined to cast Brandeis as an advocate of judicial self-restraint. Frankfurter, for example, told Hurst in 1938 that Thompson "bothered" him, and he suggested that Brandeis was not following "his own canons of constitutional adjudication." If

that the public's interest in the natural gas industry was "obviously not for the amateur lightly to decide" and wondered how Brandeis could tell whether the district judge had abused his discretion in finding no substantial evidence of waste when the record did not make clear what evidence had been before the Commission. "No. 89, Thompson et al., R.R. Comm. of Texas v. Consolidated Gas Utilities Corp. (W.D. Tex. 1936): Re. the conflicts in evidence, and findings," 20 December 1936, 4, 15, ibid.

80. "No. 89, Thompson et al., R.R. Comm. of Texas v. Consolidated Gas Utilities Corp. (W.D. Tex. 1936): Re. Construction and Constitutional Issues," 7 January 1937, reel 27, ibid.; Thompson v. Consolidated Gas Utils. Corp., 69-70.

81. "No. 89, Thompson, et al., R.R. Comm. of Texas v. Consolidated Gas Utilities Corp. (W.D. Tex. 1936): Re. Findings for use in opinion, and conflicts of evidence," 18 December 1936, reel 26, LDB-HLS; "No. 397, Henderson Co. v. Thompson, et al. (W.D. Tex. 1936): Re. draft of opinion," 20 February 1937, 4, ibid.; Henderson Co. v. Thompson, 300 U.S. 258, 264 (1937). 
Hurst also believed Brandeis was wilfully manipulating his own principles, how could he have declared, years later, that the justice "leaves to lawyers no legacy more important than his example of the responsible holding of power"? ${ }^{82}$

Perhaps Frankfurter's passing verdict on Thompson, delivered almost two decades later, provides a clue. In the same address on John Marshall that prompted Hurst to call for a Harvard-sponsored conference on Al Smith, Frankfurter claimed that Brandeis could not possibly have been motivated by "narrow economic views" in deciding the case. Rather, by protecting property in the circumstances it presented, Brandeis believed he was upholding "an aspect of liberty." Hurst might similarly have believed that, although Brandeis accepted legislative intervention into the market, the justice thought that an administrative state capable of regulating all walks of economic life on its own initiative held greater potential for evil than concentrated power in private hands. As Hurst once told Charles Wyzanski, "The justice's skepticism of men's capacity to handle themselves well in the face of demands made by the great institutions they had set up, extended fully, I think, to government." Thompson might have upset the legislative expression of the popular will, but only to prevent the creation of an administrative body capable of more wide-ranging and intrusive incursions into civil society. Such reasoning might have struck Hurst as being consistent with Brandeis's "working philosophical frame for action," even though he did not share the justice's fears. ${ }^{83}$

Whatever Hurst's musings in private, in print he did not attempt to reconcile Thompson with Brandeis's commitment to the presumption of constitutionality. True, in his Curti Lectures of 1981 Hurst wrote that "as citizen, Brandeis urged the wisdom of restraint in invoking the force of law and the desirability of maintaining the freedom of genuinely competitive markets." He supported this claim with Brandeis's testimony before Congress in 1915: "wherever you do not have to curtail liberty, wherever the exercise of full liberty by a businessman is consonant with the public welfare, public policy demands that we should allow him that liberty, because freedom is the fundamental basis of our Government and of our prosperity." He added Brandeis's advice to the reformer Robert Bruere in 1922: "Remedial institutions are apt to fall under the control of the enemy and to become instruments of oppression." But when Hurst turned to consider Brandeis "as judge," he insisted that the justice "would leave to legislatures broad scope

82. Frankfurter to Hurst, 10 June 1938, reel 39, FF-HLS; Hurst, "Tribute," 2; see Clyde Spillenger, "Reading the Judicial Canon: Alexander Bickel and the Book of Brandeis," Journal of American History 79 (1992): 125-51.

83. Frankfurter, "John Marshall and the Judicial Function," 20; Hurst to Wyzanski, 20 March 1954, Box 1, JWH-UWA; Hurst, “Tribute," 2. 
for making reasonable determinations when legislation regulating the private market would serve the public interest." In support Hurst cited Brandeis's opinions in O'Gorman \& Young and New State Ice. Some acknowledgment of Thompson is, in retrospect, conspicuous by its absence. ${ }^{84}$

\section{Life's Work}

In the autumn of 1937 Hurst joined the law faculty of the University of Wisconsin in Madison, a short train ride from his hometown. Among those who greeted the young professor with some skepticism was a student named Clark Byse. In one of their first discussions Byse asked Hurst whether he did not think he ought to have practiced law before trying to teach it. Hurst, who had turned down an offer from Solicitor General Stanley Reed to join Garrison's law school, replied that the same question had occurred to him. He had asked Brandeis for his advice and had been satisfied with the justice's reply. "It is time for you to be about your life's work," the justice had said. ${ }^{85}$

Hurst conceived of that work as the fashioning of a legal pedagogy and jurisprudence to justify the twentieth-century growth of administrative capacity in the United States without sacrificing the traditional values of American democracy. As a law professor he charted his own path between laissez-faire and socialism, guided by the notion of law as a "sustained ordering of values," expressed in a wide variety of exercises of official power that were functional to the full social development of the individuals within its domain. He would train lawyers to think of themselves not so much as officers of the court as "officer[s] of the state" and to use law in all its forms to address the needs of society. He would make good Pound's promise of a "sociological jurisprudence" by writing history that identified the values of a humane society and showed how they could be advanced in particular historical contexts. He would usually conclude that common law courts could not meet the challenges of modern societies on their own, but he would invariably stop short of a call for aggressive planning by a centralized state. Like Brandeis, he believed that such planning called for more virtue and rationality than the planners could possibly possess. "The key problem," he

84. James Willard Hurst, Law and Markets in United States History: Different Modes of Bargaining among Interests (Madison: University of Wisconsin Press, 1982), 118. I am grateful to Charles $\mathrm{W}$. McCurdy for drawing my attention to this passage.

85. Stanley Reed to Willard Hurst, 18 May 1937, Box 243, Stanley Reed Papers, University of Kentucky; Interview of Clark Byse, 20 December 1997. Byse quickly became an admirer. Lloyd K. Garrison to Hurst, 24 December 1937, Box 43, General Correspondence, WLS-UWA. 


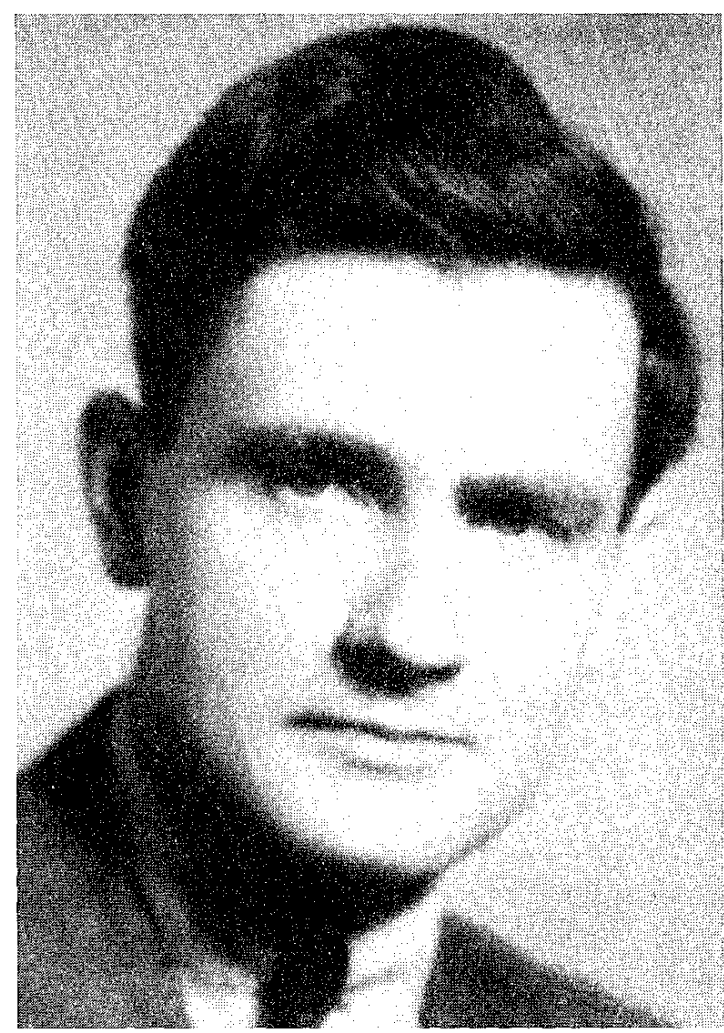

Fig. 2. James Willard Hurst, University of Wisconsin Law Faculty, 1941. Courtesy of the University of Wisconsin Law School.

wrote in 1942, "will be whether we can devise interacting schemes, or plot interrelated regions of official and non-official direction of the economy, so as not to overload the official machinery hopelessly beyond the capacity of ordinary human foresight and strength." 86

In time Hurst would find some of his most fundamental assumptions challenged by a younger generation. When student radicals at Madison quoted Walden and denounced the "expediency" of interest-group politics, Hurst retorted that "Thoreau's wholesale rejection of legal processes as instruments of humane values is a piece of utopian self-righteousness which, insofar as it is not empty, is calculated to hurt rather than help the human condition." Echoing Cozzens, he implicitly likened the student radical to "someone who at age eight discovered there was no Santa Claus and

86. Hurst, "Old and New Dimensions," 3; Hurst, "The Content of Courses in Legislation," University of Chicago Law Review 8 (1941): 294; Hurst, "Research Program," 332. 
never got over it." 87 When his colleague Mark Tushnet observed that "the real is only contingent, not the inevitable consequence of "the human condition," Hurst replied, "You and I may differ on whether there is some reality in a 'human condition' which is likely to pose problems of the control of organized power in any social system of a sort the world has yet known." And when another colleague, Robert Gordon, objected that "Functionalism assumes a main event, a something else called 'society' or 'social change' that law is functional to" and added that "the something else has to be invented by the theorist," Hurst insisted that the law responded to "stubborn realities of fact out there in the world of experience." 88

From his students days in the 1930s through the antiwar movement of the 1960s and 1970s, Hurst's career spanned what the historians Steve Fraser and Gary Gerstle have termed "an epoch in the nation's political history," the New Deal order. Of course Hurst's career was atypical in the seriousness, intelligence, and independence with which he pursued a functionalist understanding of the Rule of Law applicable to all branches of an active state. And yet future research might well show that many lawyers of his generation shared his most basic assumptions and did so out of a similar attempt to relate their own experiences to the history of their times. One thing seems certain. For Hurst the most stubborn realities were two from his young adulthood: the privations of the Great Depression and the inestimable contributions of the administrative state to the living of "lives of good conscience and fulfillment." 89

87. James Willard Hurst, “Thoreau, Conscience and Law," South Dakota Law Review 19 (1974): 38; Hurst, "Modern American Legal History," cassette 13, side 2; Cozzens, Just and the Unjust, 434. For Hurst's recollections of the "self-righteous intolerance" of some of his students, see Hurst, Smail Interview, 93-96.

88. Hurst to Mark V. Tushnet, 15 June 1981, JWH-AFM; Robert W. Gordon to Willard Hurst, 15 November 1981, ibid.; Hurst to Gordon, n.d. [1981], ibid.

89. Gary Gerstle and Steve Fraser, "Introduction," The Rise and Fall of the New Deal Order, ed. Steve Fraser and Gary Gerstle (Princeton: Princeton University Press, 1989), ix; Hurst, "Thoreau, Conscience and Law," 38. 